УДК 378.091.12.01.3-051

DOI:

Марина Васильєва, викладач кафедри англійської філології Харківського національного педагогічного університету імені Г.С.Сковороди

\title{
ОСОБЛИВОСТІ ДІЯЛЬНОСТІ ВИКЛАДАЧА ІНОЗЕМНОЇ МОВИ В РІЗНОВІКОВІЙ НАВЧАЛЬНІЙ ГРУПІ
}

У статті обтрунтовано необхідність вивчення особливостей діяльності викладача іноземної мови в різновіковій навчальній групі, досліджено індивідуально-психологічні особливості слухачів різного віку. Вивчено труднощі, з якими стикаються у навчання дорослі слухачі. Проаналізовано професійні компетениії, якими повинен володіти викладач іноземної мови для роботи у різновіковій навчальній групі. Основним методом навчання різновікової групи є комунікативний метод. Авторка виділяє основні принципи ефективного навчання у різновіковій навчальній групі.

Ключові слова: різновікова група; індивідуально-психологічні особливості; професійна компетенція; комунікативний підхід; методи та прийоми навчання.

Jim. 6.

Maryna Vasylieva, Lecturer of the English Philology Department Kharkiv Hryhoriy Skovoroda National Pedagogical University

\section{FEATURES OF EDUCATIONALACTIVITY OFTHE FOREIGN LANGUAGE TEACHER'S IN A MULTI-AGED GROUP}

The article substantiates the necessity of studying features of a foreign language teacher's educational activities in a multi-aged group. Individual and psychological peculiarities of students and learning differences of young people, college-age students and adults are studied. Difficulties faced by adult students are investigated. Features of teaching and educational process in a multi-aged group are considered. The professional competence of a foreign language teacher is viewed as the unity of psychological, theoretical and practical readiness and the ability to conduct successful pedagogical activity of foreign language teaching in a multi-aged group of learners. It is determined that the purpose of teaching a foreign language in a multi-aged group is the formation of students' communicative competence and the main method of teaching is the communicative method. It is proved that working in a multi-aged group involves certain experience of a teacher, his or her knowledge of developmental and pedagogical psychology, professional competence, knowledge of modern teaching methods, features of using the latest educational technologies, ability to apply different methods and techniques while working, being ready for self-developement and practical activity improvement. A teacher's personality plays an important role in teaching in a multi-aged group. All of the above-mentioned components of a teacher's pedagogical activity in a multi-aged group of learners are relevant considering the European integration of Ukraine's educational space. Taking into account individual psychological peculiarities of multi-aged students, features of teachers' professional competence and the purpose of teaching a foreign language, the main principles of effective teaching in a multi-aged group of students were pointed out.

Keywords: multi-aged group; foreign language; individual psychological features; professional competence; communicative approach; teaching methods and techniques.

П остановка проблеми в загальному вигляді. Останнім часом в Україні та більшості країн світу спостерігаємо підвищення інтересу до вивчення іноземних мов, що пов'язане із стрімким розширенням міжнародних контактів в аспекті глобалізації світу. Мови міжнародного спілкування (у 18 - 19 ст. французька та німецька, 20 - 21 ст. - англійська) використовуються в дипломатії, науці, освіті, культурі, галузі туризму, бізнесу та інших сферах діяльності людини. Іноземна мова є обов'язковою дисципліною освітніх програм навчальних закладів багатьох країн світу. Сучасні інтеграційні процеси в Україні відкривають безліч можливостей для людей різного віку ознайомитися і прийняти участь в освітніх, культурних, економічних, бізнесових, медичних та інших досягненнях світової цивілізації. Першочергове значення в цьому процесі набуває оволодіння іноземною мовою як засобом спілкування.

Опанувати іноземну мову сьогодні можна в умовах закладів вищої освіти, як на філологічних так і на немовних факультетах, курсах підготовки та перепідготовки кадрів, на курсах іноземних мов. Неабиякою популярністю користуються корпоративне навчання та університети третього віку.

Специфіка організації будь-якого навчання обумовлюється особливостями контингенту слухачів, а також метою, змістом та умовами 


\section{ОСОБЛИВОСТІ ДІЯЛЬНОСТІ ВИКЛАДАЧА ІНОЗЕМНОЇ МОВИ В РІЗНОВІКОВІЙНАВЧАЛЬНІЙ ГРУПІ}

навчання. В умовах курсів іноземних мов присутність в одній групі слухачів учнів середніх шкіл, студентів вишів та дорослих є звичним явищем. В аудиторії студентів закладу вищої освіти все частіше можна побачити осіб як юнацького, так і дорослого віку.

Аналіз основних досліджень і публікацій, в яких започатковано розв'язання даної проблеми. Вивчення особливостей навчання іноземних мов у студентській аудиторії в умовах вишів привертало увагу багатьох вітчизняних i зарубіжних вчених. Так, Г. Артамонова, Р. Безлюдний, Ю. Дегтярьова, І. Коваль, Ю. Колісник досліджували особливості викладання іноземної мови за професійним спрямування у немовних навчальних закладах. Дослідження І. Гіренко та Ю. Павловської присвячені питанням методики викладання іноземних мов у студентській аудиторії. Наукові пошуки Н. Гордієнко та Ю. Лаптінової торкалися окремих аспектів роботи викладача вищої школи у різнорівневих групах.

Численні роботи науковців В. Буренко, О. Гладкової, Т. Григор'євої, Р. Сфимової, Є. Кривоносової, Т. Модестової, Є. Семенової, О. Шум присвячені особливостям навчання іноземної мови дорослих. Вчені Т. Польшина, Д. Старкова, В. Тилець, Л. Цвяк, О. Щербина вивчали психологічні особливості навчання іноземних мов у дорослому віці. Дослідження О. Баніт, Р. Преснер, О. Тарнопольського стосуються організаційно-педагогічних умов навчання дорослих поза межами закладів вищої освіти. Але, нажаль, в жодній $з$ вищеназваних робіт не розглядається питання навчання іноземної мови в різновіковій навчальній групі.

Мета статті - розкрити особливості діяльності викладача іноземної мови в різновіковій начальній групі; визначити основні форми та методи навчання іноземної мови в групі різного віку.

Виклад основного матеріалу дослідження. Безперечним $\epsilon$ той факт, що навчання $\epsilon$ процесом, який передбачає активність його суб'єктів. Окремим питанням взаємодії суб'єктів процесу присвячені роботи А. Адлер, Б. Ананьєва, А. Бандури, В. Бехтєрєва,Дж. Брунер, Л. Виготського, К. Левіна, О. Леонтьєва, В. М'ясищева, К. Роджерса, С. Рубінштейна, Е. Холл, К. Хорні та ін. Характер діяльності кожного із суб'єктів зумовлюється його призначенням як учасника навчального процесу. Головна задача вчителя полягає в тому, щоб навчити, завдання учня - навчитися. Учитель повинен забезпечити учню можливість оволодіти іншомовним мовленням у процесі навчання, а учень повинен докласти зусиль, щоб цим мовленням оволодіти. Учитель організує навчальну діяльність учня, учень їі реалізує [5].

Організація навчального процесу вимагає врахування його психологічних та педагогічних складових. Слухач $є$ суб'єктом навчання, особистістю $з$ індивідуальними та віковими особливостями, які педагог має обов'язково враховувати. Саме тому в умовах, коли у навчальній групі поєднано слухачів різного віку, викладачеві слід орієнтуватись на особливості комфорту та сприйняття навчального матеріалу кожного $з$ присутніх.

Розглянемо характерні відмінності дорослих слухачів і студентів юнацького віку, які необхідно враховувати викладачу під час планування занять у роботі з різновіковою навчальною групою.

У праці С. Вершлоського “Дорослий як суб’єкт освіти" зазначено, що для студента освіта є домінуючим видом діяльності, тоді як дорослі відносяться до освіти досить прагматично. Дорослу людину цікавить насамперед “практичний результат навчання, який пов'язаний 3 можливістю застосувати нові знання і вміння, отримати новупрофесію, підвищити свій соціальний або професійний статус і т.д.” $[1,4]$.

Дорослі слухачі найчастіше більш вмотивовані до навчання у порівнянні 3 школярами та студентами, вони психологічно налаштовані на отримання результату, краще усвідомлюють необхідність вивчення іноземної мови для використання в особистому спілкування, для подорожі, просування кар'єрними сходами. Вони прагнуть до застосування набутих знань на практиці у повсякденному і професійному житті. При цьомудорослий часто висуває високі вимоги стосовно якості та результатів навчання, він буде вивчати тільки те, що вважає необхідним. На відміну від слухачів юнацького віку, дорослі суб'єкти навчання усвідомлюють себе самостійними самокерованими особистостями, які мають певний життєвий і навчальний досвід. Слухачам юнацького віку не завжди вдається свідомо регулювати свою поведінку та навчальну діяльність. Часто молоді люди вдаються до невмотивованого ризику, не завжди можуть передбачити наслідки своїх вчинків. Серед юнаків нерідко спостерігаємо недостатню мотивацію, бажання відкласти виконання завдання на останній момент, відсутність уміння планувати свій час. Під час роботи с такими студентами викладачеві слід більше уваги приділяти управленню навчальною діяльністю слухачів. У роботі з дорослими важливо враховувати наявність у слухачів певного життєвого досвіду, а також низку вікових, соціальних і психологічних 


\section{ОСОБЛИВОСТІ ДІЯЛЬНОСТІ ВИКЛАДАЧА ІНОЗЕМНОЇ МОВИ В РІЗНОВІКОВІЙ НАВЧАЛЬНІЙ ГРУПІ}

особливостей. Щодо особливостей опанування іноземної мови, дорослі люди мають певні переваги перед молоддю. Нервові клітини, відповідальні за семантичний аналіз слів і граматичну сприйнятливість, 3 віком розвиваються. Дорослим слухачам набагато легше зрозуміти структуру мови. Пізнавальна система дорослих $є$ більш розвиненою, ніж у юних слухачів. Вони можуть робити узагальнення вищого порядку. Доросла людина зазвичай має відпрацьований арсенал прийомів та засобів, що полегшують запам’ятовування. Більш молоді і юні слухачі краще відкриті новому, легше засвоюють лексику, а також, що надзвичайно важливо при вивченні мови, володіють вираженою здатністю імітування і наслідування (на жаль, з роками, вона поступово згасає, хоча ступінь цього згасання для всіх дуже індивідуальна).

Проте у роботі 3 дорослою аудиторією викладачеві необхідно враховувати ряд психологічних бар'єрів. Дорослим людям не завжди комфортно знову опиниться в ролі учня, особливо в умовах присутності молоді у групі. Вони можуть відчувати непокоєння з приводу того, що зазнають невдачі. Дорослі слухачі відчувають страх допустити помилки, невпевненість у власних силах. Більшість дорослих негативно відносяться до оцінювання своїх знань. Крім того, вони зазвичай вивчають мову, поєднуючи навчання з роботою, а отже не завжди мають достатньо часу для виконання домашніх завдань, закріплення та відпрацювання отриманих знань.

Реальність вирішення зазначених проблем створенням одновікових груп стає досить сумнівною в умовах диверсифікації форм навчання.

Таким чином, вбачаємо досить вагомі причини формування у майбутніх викладачів іноземних мов компетенції роботи в різновіковій групі.

Професійна компетентність викладача іноземної мови розглядається нами як єдність психологічної, теоретичної і практичної готовності та здатності до здійснення успішної педагогічної діяльності в навчанні іноземної мови в різновіковій навчальній групі.

На думку С. Ніколаєвої, компетентність викладача іноземної мови складається з чотирьох блоків компетенцій: 1) іншомовна комунікативна компетенція, до складу якої входять мовна, мовленнєва та соціокультурна компетенції; 2) власне професійна компетенція, що поєднує філологічну, психолого-педагогічну та методичну компетенції; 3) іншомовна професійнокомунікативною компетенцією, у якій синтезовані мовна, мовленнєва та соціокультурна професійно орієнтовані компетенції; 4) загальна компетенція, яка об'єднує інструментальну, міжособистісну та системну компетенції $[6,15]$. Ці компетенції слід вважати базовими для викладача іноземної мови в різновіковій навчальній групі, втім їх перелік потребує доповнення й розширення 3 огляду на особливості навчально-виховного процесу в групі слухачів різного віку.

Іншомовна комунікативна компетенція передбачає наявність умінь здійснювати мовленнєвий акт, у якому реалізується комунікативно-мовленнєва поведінка на основі фонологічних, лексико-граматичних, соціолінгвістичних знань і умінь відповідно до поставлених завдань, проблем і ситуацій. Комунікативна компетенція не лише передбачає володіння всіма видами мовленнєвої діяльності (аудіювання, говоріння, читання та письмо), але й культурою писемного i усного мовлення. В умовах глобалізованого суспільства та розширення міжнародного співробітництва соціокультурна компетенція викладача набуває пріоритетного значення, адже слухачі повинні не тільки оволодіти іноземною мовою як засобом спілкування, а й навчитися взаємодіяти з представниками інших мов і культур у соціокультурному просторі.

Власне професійна компетенція викладача іноземної мови передбачає поєднання знань із дидактики, вікової та педагогічної психології та методики викладання іноземних мов. Викладач, який працює у різновіковій групі повинен бути добре проінформованим про інновації в галузі конкретних методик викладання, про використання новітніх освітніх технологій, засобів навчання, форм роботи із слухачами, бути готовим до саморозвитку та вдосконалення професійної діяльності.

Викладач іноземної мови також повинен вміти аналізувати результати своєї діяльності, формувати свій індивідуальний стиль викладання, досягти адекватної професійно-особистісної самооцінки, проектувати свої зусилля у площину професійного зростання та постійного самовдосконалення, що являє собою підгрунтя рефлексивної компетенції [2].

Серед вимог до викладача, який працює в різновіковій навчальній групі обов'язковою $є$ готовність до здійснення викладацької діяльності в такій групі. Авторитетна вчена 3. Курлянд визначає готовність як якість особистості, в основі якої є підготовленість людини діяти належним чином у момент включення в певну діяльність [4]. Готовність є результатом досвіду, який акумулюється протягом певного часу в 


\section{ОСОБЛИВОСТІ ДІЯЛЬНОСТІ ВИКЛАДАЧАІНОЗЕМНОӤ МОВИ В РІЗНОВІКОВІЙ НАВЧАЛЬНІЙ ГРУПІ}

результаті певних впливів. В окремих педагогічних ситуаціях викладач проявляє тимчасову (ситуативну) готовність. Для викладача, який працює у різновіковій начальній групі, важливим $€$ проявляти постійну готовність. Готовність до педагогічної діяльності, на думку 3. Курлянд, структурно складається 3 професійної самосвідомісті, ставлення до діяльності, мотивів та певних настанов, знань про предмет, засобів діяльності, навичок і вмінь застосовувати ці засоби на практиці, а також особистих якостей викладача [4].

Викладач упроцесі роботи із слухачами різного віку повинен не просто представити матеріал, а навчити користуватися ним практично, у різних ситуаціях спілкування. Не абияку роль у досягненні цієї мети відіграють професіоналізм та особисті якості викладача іноземної мови. Особистість вчителя іноземної мови та ії̈ вплив на перебіг процесу навчання та його результат привертала увагу таких вчених як О. Дуплійчук, 3. Курлянд, О. Петрова, В. Сєдлачек, Г. Яворська.

Ми вважаємо, що науковий підхід до особистості педагога-професіонала, запропонований 3. Курлянд заслуговує на увагу. Вчена переконана, що особистість викладача повинна складатися 3 комплексу особистісних характеристик, вмінь і навичок, що допомагають ефективно включатися в педагогічну діяльність. Професійна усталеність педагога, на думку вченої, складається 3 мотиваційного, емоційного, особистісного та професійно-педагогічного компонентів. Мотиваційний компонент викладача свідчить про наявність в нього мотивації на досягнення результату, впевненість у собі, задоволеність процесом та результатом навчальної діяльності. Емоційний компонент виявляється в умінні викладача керувати своїми емоціональними станами, відсутності емоційного напруження, умінні створювати позитивну атмосферу на занятті, відсутності страху перед аудиторією дорослих слухачів різного віку. Особистісний компонент містить уміння здійснювати методологічну рефлексію, швидко і адекватно реагувати на поведінку слухачів. Професійнопедагогічний компонент діяльності викладача свідчить про знання, вміння та досвід педагога, уміння приймати вірні рішення у нетипових навчальних ситуаціях, наявність потреби у самопізнанні, самореалізації та самовдосконаленні [4].

Усі вище згадані складові педагогічної діяльності викладача є невід'ємними у роботі в сфері євроінтеграції освітнього простору України.

На нашу думку, для викладача, який працює у різновіковій навчальній групі, необхідним $\epsilon$ i наявність елементу творчості в педагогічній діяльності (диспути, обговорення, проекти, дослідження, кейс-навчання, квести). Це надає змогу педагогові створити слухачам умови для виконання певних видів проблемних завдань, що дозоляє проявити творчий потенціал, індивідуальні здібності, застосувати набуті знання в цікавій неординарній формі.

Згідно з загальноєвропейськими рекомендаціями Ради Європи, метою навчання будь-якої іноземної мови $є$ вільне спілкування цією мовою, тобто формування у слухачів іншомовної комунікативної компетенції. Під комунікативною компетентністю розуміють “здатність здійснювати спілкування за допомогою мови, тобто передавати думки й обмінюватися ними в різних ситуаціях у процесі взаємодії з іншими учасниками спілкування, правильно використовуючи систему мовних норм і вибираючи комунікативну поведінку, адекватних ситуації спілкування" [3, 54]. Іншомовна комунікативна компетенція складається 3: мовленнєвої компетенції (аудіювання, говоріння, читання, письмо); мовної компетенції (лексичні, фонетичні, орфографічні знання); дискурсивної компетенції; соціокультурної та соціолінгвістичної компетенції, стратегічної компетенції. Слухач повинен уміти здійснювати усне спілкування, розуміти на слух різну інформацію, логічно структурувати і передавати свої висловлювання, обирати ефективні стратегії для розв'язання будьякої проблеми. Комунікативний метод навчання іноземних мов базується на тому, що процес навчання $є$ моделлю комунікації. Основними принципами комунікативного методу є: принципмовленнєво-розумової діяльності; принцип індивідуалізації при керівній ролі особистісного аспекту; принцип функціональності; принцип ситуативності; принцип новизни.

Беручи до уваги індивідуально-психологічні особливості слухачів різного віку, особливості професійної компетентності викладачів та мету навчання іноземної мови, можна виділити такі принципи ефективного навчання у різновіковій навчальній групі: підтримка мотивації студентів групи; врахування індивідуально-психологічних особливостей слухачів; формування впевненості і навчального потенціалу слухачів; знання потреб слухачів та їхніх стратегій опанування відповідної теми; раціональний розподіл діяльності у часі; вміння представити мову як систему взаємопов'язаних елементів; використання різних методів навчання; підбір навчальних матеріалів, що відразу використовують декілька органів чуття; опора на сформовані навички і засвоєні 
знання; адекватна реакція викладача на емоційні прояви аудиторії; використання методів і прийомів, які зменшують вплив рідної мови; ефективне використання парних, групових і самостійних прийомів роботи, що базуються на професійних знаннях і життєвому та мовному досвіді слухачів; підвищення професійного рівня; постійне самовдосконалення і здійснення пошуку нових підходів до навчання.

Висновки 3 даного дослідження i перспективи подальших розвідок. У зв'зку $з$ євроінтеграційними тенденціями вивчення іноземних мов в Україні стає все більш популярним серед людей різного віку та соціальної приналежності. Розподіл слухачів по групах відбувається за рівнем мовленнєвої підготовки, а не за віком, саме тому в одній навчальній групі можуть знаходитися слухачі з різницею у віці в декілька десятиліть. Робота у різновіковій навчальній групі передбачає наявність у викладача певного досвіду, знання вікової та педагогічної психології, наявність професійної компетенції, знання сучасних методик викладання, уміння застосовувати різні методи та прийоми в роботі.

Перспективами подальших розвідок вважаємо вивчення позитивних та негативних аспектів вивчення іноземної мови в різновіковій навчальній групі.

\section{ЛІТЕРАТУРА}

1. Вершловский С. Г. Взрослый как субъект образования / С. Г. Вершловский // Педагогика: научно-теоретический журнал - Москва, 2003. №8. - С. 3 - 8 .

2. Желанова В.В. Використання технологій формування рефлексивної компетентності в процесі професійної підготовки вчителя початкових класів / В.В. Желанова // Наукові записки Вінницького державного педагогічного університету імені Михайла Коцюбинського. Серія: Педагогіка і психологія: зб. наукових праць. - Вип. 27, 2009. - С. 132 - 136.

3. Колодько Т.М. Моделювання змісту підготовки майбутнього вчителя іноземної мови до реалізації іншомовної освіти / Т.М. Колодько // Імідж сучасного педагога. - № 6 (175). - 2017. C. 54 - 58. - Режим доступу: http://isp.poippo.pl.ua/ article/view/119166
4. Курлянд3.Н.Педагогікавищоїшколи/3.Н. Курлянд. // - К.: Знання - 2005. - 399 с.

5. Бігіч О.Б. Методика викладання іноземних мов у середніх навчальних закладах: Підручник / О.Б. Бігіч, Н.О. Бражник, С.В. Гапонова та ін. За наук. ред. Ніколаєвої С. Ю. - К.: Ленвіт, 2002. $328 \mathrm{c}$.

6. Ніколаєва С.Ю. Основи сучасної методики викладання іноземних мов (схеми і таблиці): [навч. посіб.] / С.Ю. Ніколаєва // - Київ: Ленвіт, 2008. - 258 с.

\section{REFERENCES}

1. Vershlovskij, S. G. (2003). Vzroslyj kak subekt obrazovanija [An adult as the subject of education]. Pedagogy: the scientific and theoretical journal. Moscow, vol. 8, pp. 3-8. [in Russian].

2. Zhelanova, V.V. (2009). Vykorystannia tekhnolohii formuvannia refleksyvnoi kompetentnosti v protsesi profesiinoi pidhotovky vchytelia pochatkovykh klasiv [Using the technology for reflexive competence formation in the process of primary school teachers professional education]. Scientific notes of the Vinnytsya Mykhaylo Kotsyubynskiy State Pedagogical University. Series: Pedagogy and Psychology: A collection of scientific works. Vinnytsa, vol. 27, pp. 132-136. [in Ukrainian].

3. Kolodko, T.M. (2017). Modeliuvannia zmistu pidhotovky maibutnoho vchytelia inozemnoi movy do realizatsii inshomovnoi osvity [Modelling the content of future foreign language teacher's preparation for the implementation of foreign language education]. The image of a modern educator. Electronic scientific professional journal. Vol. 6(175), pp. 54-58. Available at: http://isp.poippo.pl.ua/article/view/119166 [in Ukrainian].

4. Kurliand, Z. N. (2005). Pedahohika vyshchoi shkoly [Higher school pedagogy]. Kyiv: Znannia, 399 p. [in Ukrainian].

5. Bihich, O.B., Brazhnyk, N.O., Haponova, S.V. et al. (2002). Metodyka vykladannia inozemnykh mov u serednikh navchalnykh zakladakh [Methods of teaching foreign languages in secondary educational establishments]. (Ed.). Nikolaieva, S. Yu. Kyiv: Lenvit, 328 p. [in Ukrainian].

6. Nikolaieva, S. Yu. (2008). Osnovy suchasnoi metodyky vykladannia inozemnykh mov (skhemy $i$ tablytsi) [Basics of modern methods of foreign language teaching (Schemes and tables)]. Kyiv: Lenvit, 258 p. [in Ukrainian].

Стаття надійшла до редакщії 13.09.2018

\section{G58080}



